\title{
Effect of Cassava Starch and Sodium Carbonate on the Properties of Local Drilling Mud: Beneficiation to Improve the Rheological and Flow Properties of Locally Formulated Mud
}

\author{
Andrew Odeh, Redemption Edegbe, Eghe Oyedoh \\ Department of Chemical Engineering, Faculty of Engineering, University of Benin, Benin, Nigeria \\ Email: andrew.odeh@uniben.edu
}

How to cite this paper: Odeh, A., Edegbe, R. and Oyedoh, E. (2022) Effect of Cassava Starch and Sodium Carbonate on the Properties of Local Drilling Mud: Beneficiation to Improve the Rheological and Flow Properties of Locally Formulated Mud. Advances in Chemical Engineering and Science, 12, 13-25.

https://doi.org/10.4236/aces.2022.121002

Received: October 27, 2021

Accepted: January 4, 2022

Published: January 7, 2022

Copyright ( 2022 by author(s) and Scientific Research Publishing Inc. This work is licensed under the Creative Commons Attribution International License (CC BY 4.0).

http://creativecommons.org/licenses/by/4.0/

(c) (i) Open Access

\begin{abstract}
Drilling mud is a key component in drilling operations and in accessing oil and gas reservoirs. Bentonite is applied as a viscosifier, fluid loss control agent, and as a weighting material in water-based drilling mud. The type of bentonite used in drilling mud formulation is sodium bentonite due to its high dispersion properties and high swelling capacity. Nigeria has a huge bentonite clay deposit resources which can be evaluated and enhanced in order to be utilized as drilling mud. However, bentonite clay from different parts of Nigeria was investigated and found to be calcium bentonite which is not suitable for drilling mud, because it has low swelling capacity and poor rheological properties. In this study, local bentonite obtained from Afuze, Edo state was used to formulate different samples of drilling mud with each treated using thermo-chemical beneficiation process with sodium carbonate and cassava starch, and then undergo characterization to identify the changes in physical properties and finally, draw comparison with API values for standard drilling mud. The results obtained from this study indicates that, the flow and rheological properties of the beneficiated drilling mud developed through thermo-chemical treatment, showed significant improvement compared to the untreated mud. Therefore, pure calcium bentonite from natural deposits in Nigeria can be modified to sodium bentonite and sufficiently used in drilling mud formulation.
\end{abstract}

\section{Keywords}

Drilling Mud, Bentonite Clay, Beneficiation, Cassava Starch, Rheological Properties, Characterization, Oil and Gas Reservoir 


\section{Introduction}

As one of the largest oil producers in the world, the present consumption of bentonite clay in the drilling operations in Nigeria alone is over 100 thousand tons a year [1]. This large consumption has led to various attempts in finding a local substitute which can save a huge amount of hard currency that otherwise would be spent on importation [2].

Drilling muds, oil or water-based, are made up of clays, water, weighing materials and chemical additives used to flush cuttings from the drill bit to the surface. The most common type of clay used in drilling mud formation is the bentonite clay. Bentonite clay is deposited in millions of tons across various locations in Nigeria which includes but not restricted to; Edo, Delta, Imo, Yobe, Borno and Kebbi States [3]. The properties and formulation of drilling fluids play a fundamental role in drilling operations [4]. Since the success of drilling operations depends on the correct selection of the drilling fluid system [5], most of the bentonite used in the Nigerian mud formulation is imported to avoid disasters associated with the use of inferior quality bentonite. The under-utilization of the Nigerian bentonite clay is predominantly due to its major constituent. It has been found that Nigeria bentonite has defects in fluid loss and rheological properties (including yield point). In addition, due to the high calcium content and low sodium content compared with foreign bentonite, it does not meet the API drilling standards. Due to these or more difficulties, Nigeria's bentonite used in drilling activities is mainly imported into the country [6]. A lot of studies and researches have been focused on characterizing and beneficiating our local clay to the American Petroleum Institute (API) standard [7]. Although Nigerian bentonite has a large number of mineral deposits all over the country, it has not been widely used due to its excessive water loss and low swelling index [8].

In terms of foreign exchange, the Nigerian economy is highly dependent on the oil and gas industry. Over the years, researchers have confirmed that drilling activities carried out by oil companies require the import of materials required for fluid formulations or the import of custom drilling fluids specifically designed to meet the needs of the formation of the Niger Delta [9]. The costs associated with importing these materials can reach millions of dollars each year, affecting the nation's gross domestic product (GDP) and eventually the economy [10]. Importing bentonite for drilling in the oil and gas industry continues to change the huge amount of foreign exchange that can be used in Nigeria's socio-economic stability budget [11]. Due to these or more difficulties, Nigeria's bentonite used in drilling activities is mainly imported into the country [12]. Before this clay can be used to prepare drilling mud, sufficient measures have to be taken to modify it. It is also important and appropriate to enhance the properties of this clay. This particular demand has increased research on the use of local clays in drilling fluid applications in the oil and gas industry. As interest in bentonite usage in oil and gas industries increases, the properties of Nigerian bentonite need to be improved to meet API standards [13]. 
Cassava is one of the most abundant substances in nature with starch being its main constituent as about $25 \%$ starch may be obtained from mature, good quality tubers [14]. Ademiluyi et al. [1] investigated the use of local cassava starch instead of imported samples from the viscosity and fluid loss control of aqueous mud. Igbani et al. [8] also studied using cassava starch powder and found that it could improve the density of drilling fluids. The results from both studies indicated that the local cassava imported samples had similar or better filtration control properties, but the viscosity of the drilling fluid produced from the local starch was also lower than that of the imported type. Therefore, a thorough study of local cassava is needed, in order to study their properties and develop a slurry formulation which can perform the same function as the imported additives. This will reduce the cost of some of the expensive viscosifiers and fluid loss agents that are imported and will also create jobs. Hence, this study evaluates the performance of local cassava as a viscosity enhancer and demulsifier in water-based drilling mud.

Beneficiation is a process which involves the addition of chemical additives like sodium carbonate $\left(\mathrm{Na}_{2} \mathrm{CO}_{3}\right)$, caustic soda $(\mathrm{NaOH})$, potassium chloride $(\mathrm{KCl})$, sodium carboxymethyl cellulose (CMC), barium sulphate $\left(\mathrm{Ba}_{2} \mathrm{SO}_{4}\right)$, starch, etc. to the mud formulation to help in improving drilling mud properties such as; free swell volume (FSV), gel strength, yield point, weight, specific gravity, viscosity, fluid loss. These additives help minimize formation damage, maintain well integrity, reduce logging analysis problems, protect water-sensitive shale, reduce fluid loss in the protective formation, and reduce well washout for better results, lining and cementing work [15] [16].

\section{Location of Study Area}

Bentonite clay used in this study was obtained from Afuze town in owan east local government area of Edo State, Southeastern Nigeria (Figure 1). Its geographical coordinates are longitude $6.04254^{\circ} 7^{\prime} \mathrm{E}$ latitude $6.96945^{\circ} \mathrm{N}$ and elevation of $440 \mathrm{ft}$ (134 meters) and this is $533 \mathrm{ft}$ (162.5 meters) below average elevation of Nigeria.

\section{Materials and Methods}

\subsection{Equipment and Raw Materials}

Table 1 shows the equipment used in this work.

Table 2 shows the equipment used in this work.

\subsection{Methodology}

\subsubsection{Cassava Starch Flour Preparation}

The cassava root variety known as azaka was uprooted, peeled and cut into small sizes which were properly washed and grated into pulp mash/paste. The pulp mash was then placed into a porous cloth and squeezed to extract as much filtrate (containing water and suspended starch) as possible which was received in 
Table 1. Details of equipment used.

\begin{tabular}{cl}
\hline Equipment & \multicolumn{1}{c}{ Function(s)/Use(s) } \\
\hline Beaker & Measurement of specific volumes of solution \\
pH meter & $\begin{array}{l}\text { For transfer and supply of measured volumes of } \\
\text { liquid }\end{array}$ \\
Sieve & For determining pH of solution \\
Electronic weighing balance & For separating unwanted particles present in the \\
crushed clay material
\end{tabular}

Table 2. Details of raw materials used.

\begin{tabular}{cccc}
\hline S/N & Raw material & Function(s) & Quantity \\
\hline 1 & Bentonite clay & Viscosity and filtration control & $20-40 \mathrm{~g}$ \\
2 & Water & Base fluid & $350 \mathrm{ml}$ \\
3 & Cassava Starch & Viscosifier and fluid loss reducer & $10 \mathrm{~g}$ \\
4 & $\begin{array}{c}\text { Sodium carbonate } \\
\left(\mathrm{Na}_{2} \mathrm{CO}_{3}\right)\end{array}$ & $\begin{array}{c}\text { Reduction of calcium content } \\
\text { via cation exchange process }\end{array}$ & $3.3-6.7 \mathrm{~g}$ \\
& $\begin{array}{c}\text { Sodium hydroxide } \\
(\mathrm{NaOH})\end{array}$ & $\begin{array}{c}\text { regulate the pH and } \\
\text { decrease corrosion }\end{array}$ & $0.3 \mathrm{~g}$ \\
\hline
\end{tabular}

a bowl. The filtrate obtained was allowed to settle under the influence of gravity for about 7 hours in order for the starch to concentrate at the bottom while the water was removed. The solid starch obtained was then placed in a flat pan and placed in the electric thermo-regulated oven for hours to remove the moisture content. The dried starch cake was then crushed and sieved to obtain fine particles and finally packaged. 


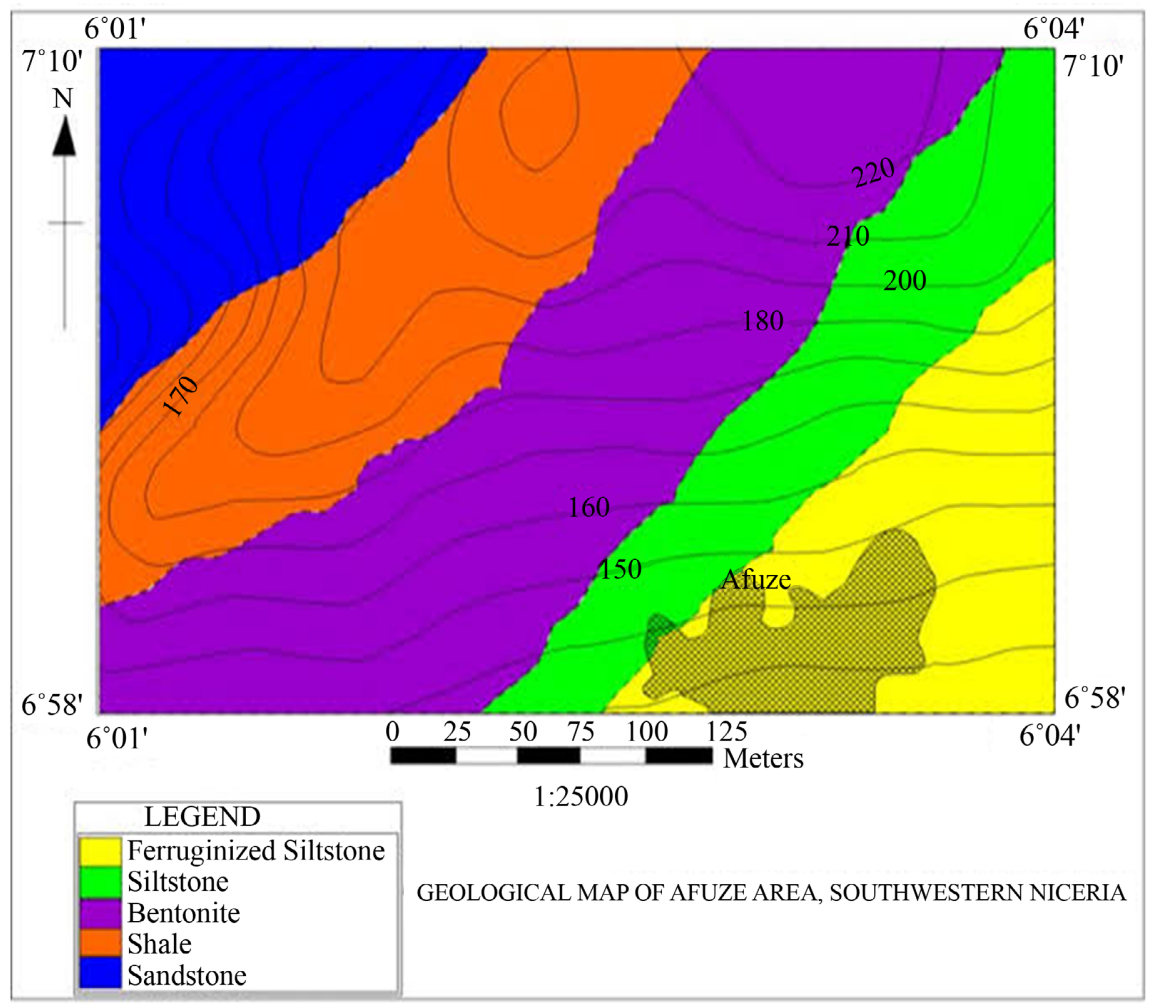

Figure 1. Geological map of Afuze.

\subsubsection{Bentonite Clay Preparation}

The bentonite clay obtained from Afuze was dried under moderate conditions and was crushed by pounding in a mortar. Sieve analysis was carried out on the crushed clay with the use of a sieve shaker using different mesh sizes to obtain fine particles. Proportions of 20 g, 25 g, $30 \mathrm{~g}, 35 \mathrm{~g}$ and $40 \mathrm{~g}$ of fine bentonite clay were weighed and placed in different beakers labelled appropriately.

\subsubsection{Preparation of Sodium Carbonate Solution}

Sodium carbonate solution formulated by dissolving sodium carbonate powder (soda ash) in distilled water. This solution served as a source of carbonate and sodium ions for an ion exchange process with Ca-bentonite, where the calcium can be precipitated as calcium bentonite [11].

\subsubsection{Preparation of the Drilling Mud}

The experimental procedure involved the addition of a bentonite clay sample to a sodium carbonate aqueous solution to form a bentonite suspension, which was stirred continuously for 1 hour $60^{\circ} \mathrm{C}$ at speed of $150 \mathrm{rpm}$ determined using a tachometer to form sodium bentonite and calcium carbonate. The calcium based bentonite was therefore converted to sodium based bentonite by combining chemical (addition of sodium carbonate), mechanical (agitation), and thermal (heating) treatment procedures. The bentonite clay sample was treated with sodium carbonate making use of a sodium carbonate bentonite weight ratio of 1:5 by varying the sodium carbonate content and bentonite concentration. The so- 
dium carbonate/bentonite weight ratios are as follows; $20 \mathrm{~g}$ of local bentonite (no sodium carbonate), $4 \mathrm{~g}$ of sodium carbonate to $20 \mathrm{~g}$ of local bentonite, $5 \mathrm{~g}$ of sodium carbonate to $25 \mathrm{~g}$ of local bentonite, $6.0 \mathrm{~g}$ of sodium carbonate to $30 \mathrm{~g}$ of local bentonite, $7 \mathrm{~g}$ of sodium carbonate to $35 \mathrm{~g}$ of local bentonite, $8 \mathrm{~g}$ of sodium carbonate to $40 \mathrm{~g}$ of local bentonite.

Upon the formation of bentonite suspension, the bentonite suspension was heated and stirred continuously with the aid of a magnetic stirrer and a magnetic stirrer hot plate. The different samples (sample 2 - 6) were subsequently treated with $10 \mathrm{~g}$ of cassava starch flour and other chemical additives such as sodium hydroxide and potassium chloride for another 15 mins to form a bentonite-starch suspension and to achieve a homogenous dispersion where the polymer chains are well confined by the clay particles.

\subsubsection{Optimization by Means of Characterization}

The various mud samples were then characterized by determining the rheological properties of the mud which consist of; plastic viscosity, apparent viscosity, yield point, mud density, specific gravity, alkalinity, and fluid loss. These parameters (plastic/apparent viscosity and yield point) were recorded with a viscometer at dial readings of 600 and $300 \mathrm{rpm}$. Formula for determining some of the aforementioned properties are;

$$
\begin{gathered}
\text { plastic viscosity }(\mathrm{cp})=600 \mathrm{rpm} \text { reading }-300 \mathrm{rpm} \text { reading } \\
\text { apparent viscosity }(\mathrm{cp})=\frac{600 \mathrm{rpm}}{2} \\
\text { yield point }\left(\mathrm{lbs} / 100 \mathrm{ft}^{2}\right)=300 \mathrm{rpm}-\text { plastic viscosity } \\
\text { mud density }(\mathrm{ppg})=\frac{\text { measured mass of a given mud sample }}{\text { volume of the sample }}
\end{gathered}
$$

where rpm is revolution per time (mins) and ppg is pounds per gallon.

The fluid loss was determined by using a filter paper attached to a measuring cylinder. Each sample was poured gradually into the set up and the volume of liquid lost from the mud is measured in the measuring cylinder.

\section{Results and Discussion}

Table 3 gives comprehensive details of results obtained from this study. Hydrogen ion concentration, $p H$ is a measure of the concentration of hydrogen ions in aqueous solution. If the water used in the preparation of a drilling mud is too hard or the $\mathrm{pH}$ value is not within the range of $8.5-9.5$, then the mud will take a longer period to hydrate, or it might not hydrate fully. Figure 2 shows a bar plot comparing the $\mathrm{pH}$ of the imported bentonite, local bentonite, and the five different samples. A critical look at the plot indicated an increase in the $\mathrm{pH}$ of the mud samples. This increase occurred as a result of the beneficiation of the mud samples by the addition of sodium carbonate $\left(\mathrm{Na}_{2} \mathrm{CO}_{3}\right)$. Sodium carbonate is alkaline in nature, as it is a strong base. The higher the bentonite and sodium carbonate concentrations, the higher 
Table 3. Overall summary of experimental result.

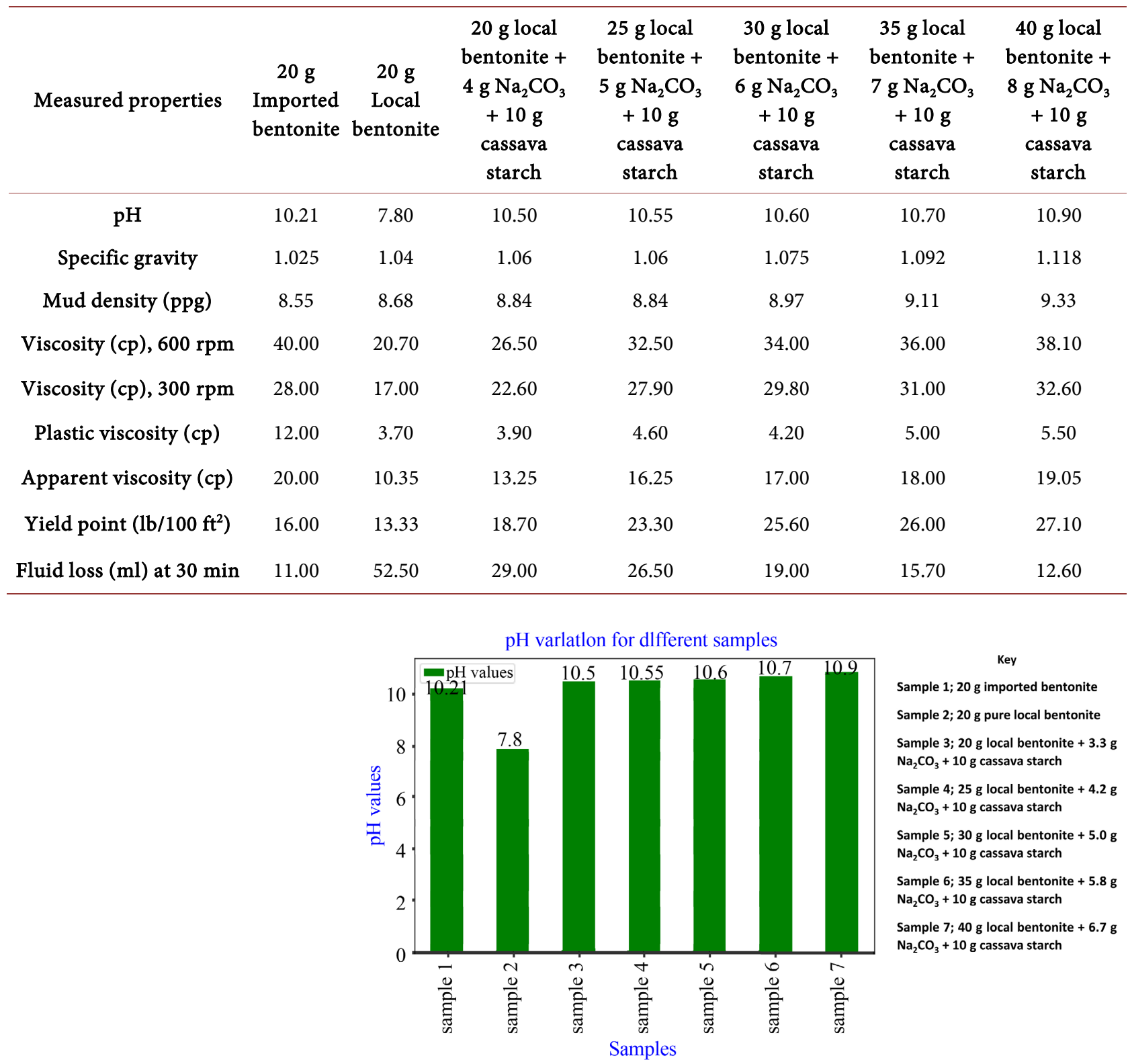

Figure 2. Bar plot showing the $\mathrm{pH}$ variation of the various samples.

the $\mathrm{pH}$ values of the mud samples. The conversion of calcium carbonate to sodium carbonate through ion exchange can also influence the $\mathrm{pH}$ of the mud samples.

Specific gravity defines the density or weight of fluid compared to the density of an equal volume of water at a specified temperature. Figure 3 is a plot showing the comparison between the specific gravity of the imported bentonite, local bentonite, and the five samples. The different readings obtained were compared with the standard bentonite and it was observed that there was also an increase in the specific gravity of the different samples. The increase in the specific gravity of samples was influenced by the addition of cassava starch to the five samples at different masses of bentonite and sodium carbonate [17]. 


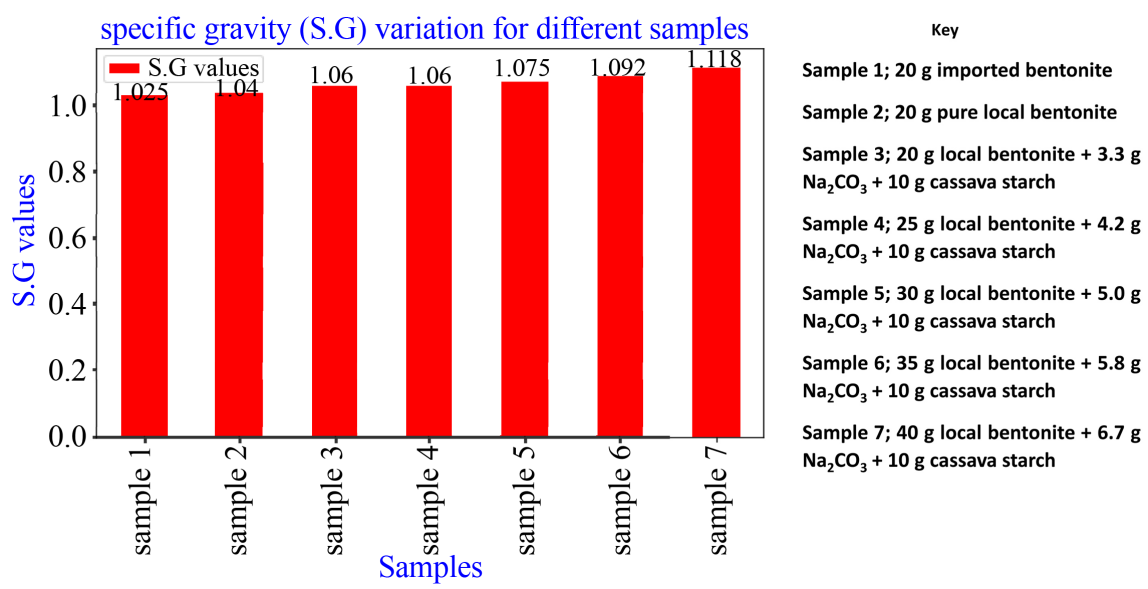

Figure 3. Bar plot showing the specific gravity variation of the various samples.

A high mud density manages the formation pressure and improves the stability of the well bore. Figure 4 is a bar plot showing the comparison between the densities of the standard bentonite, local bentonite, and the five different test samples. The different dial readings were compared with that of the imported bentonite, and it was observed that there was a progressive rise in the densities of the mud samples. An increase in mud density was greatly influenced by adding cassava starch to the different samples. Increase in the volume of the bentonite resulted in a higher effect of cassava starch on the mud samples increasing the mud density of the samples.

Mud viscosity illustrates the amount of resistance of the fluid to shear stress. For the effectiveness of the fluid to be able to remove cuttings, the fluid has to have some viscosity [16]. The viscosity of the drilling fluid can be improved upon by treatment with additives such as starch. Figure 5 shows the comparison between the viscosities at $300 \mathrm{rpm}$ and $600 \mathrm{rpm}$ of the imported bentonite, local bentonite, and the five different samples. From the chart, it was observed that there were generally poor values of viscosity of untreated local bentonite when compared with the standard mud sample. However, with beneficiation, there was an improvement in the viscosity of the treated mud samples when compared with the untreated local bentonite. Cassava starch is suitable for increasing viscosity of the clay suspension and stabilizing the clay suspension. The higher the bentonite concentration, the higher the starch effect on the viscosity of the mud samples. From the result, the most improved viscosity was observed in sample seven ( $40 \mathrm{~g}$ of bentonite $+6.7 \mathrm{~g}$ of $\mathrm{Na}_{2} \mathrm{CO}_{3}+10 \mathrm{~g}$ of starch) having the highest concentration of bentonite.

The resistance of the flow of fluids due to mechanical friction in the drilling mud such as the shape and size of solid, concentration of solid, viscosity of the fluid phase in the continuous phase is known as plastic viscosity. Figure 6 below shows the comparison between the plastic and apparent viscosities of the standard bentonite, local bentonite, and the five different samples. The values used for the plot of plastic viscosity were obtained from the difference between measurements at $600 \mathrm{rpm}$ and measurements at $300 \mathrm{rpm}$ [18]. The plastic viscosity 


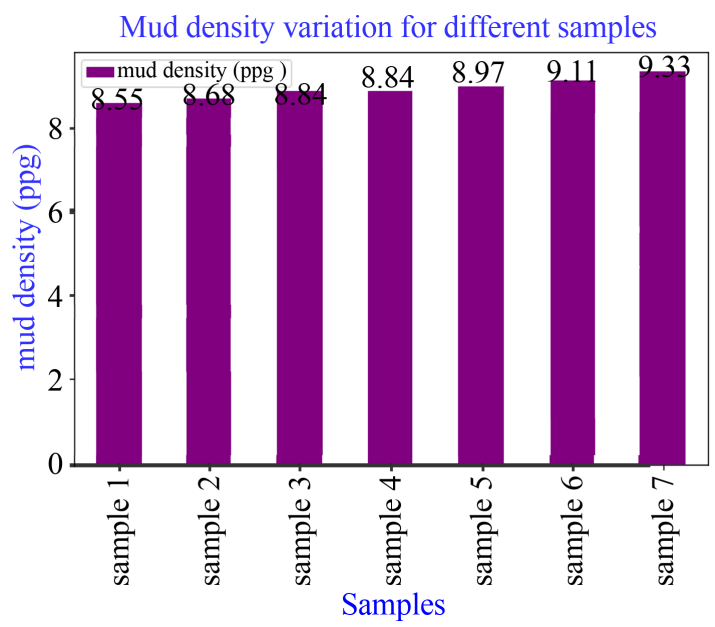

Key

Sample 1; 20 g imported bentonite Sample 2; $20 \mathrm{~g}$ pure local bentonite

Sample 3; $20 \mathrm{~g}$ local bentonite $+\mathbf{3 . 3} \mathrm{g}$ $\mathrm{Na}_{2} \mathrm{CO}_{3}+10 \mathrm{~g}$ cassava starch

Sample 4; $25 \mathrm{~g}$ local bentonite $+4.2 \mathrm{~g}$ $\mathrm{Na}_{2} \mathrm{CO}_{3}+10 \mathrm{~g}$ cassava starch

Sample 5; $30 \mathrm{~g}$ local bentonite $+\mathbf{5 . 0} \mathrm{g}$ $\mathrm{Na}_{2} \mathrm{CO}_{3}+10 \mathrm{~g}$ cassava starch

Sample 6; $\mathbf{3 5 g}$ local bentonite $+\mathbf{5 . 8} \mathrm{g}$ $\mathrm{Na}_{2} \mathrm{CO}_{3}+10 \mathrm{~g}$ cassava starch

Sample 7; $40 \mathrm{~g}$ local bentonite $+6.7 \mathrm{~g}$ $\mathrm{Na}_{2} \mathrm{CO}_{3}+10 \mathrm{~g}$ cassava starch

Figure 4. Bar plot showing the density variation of the various samples.

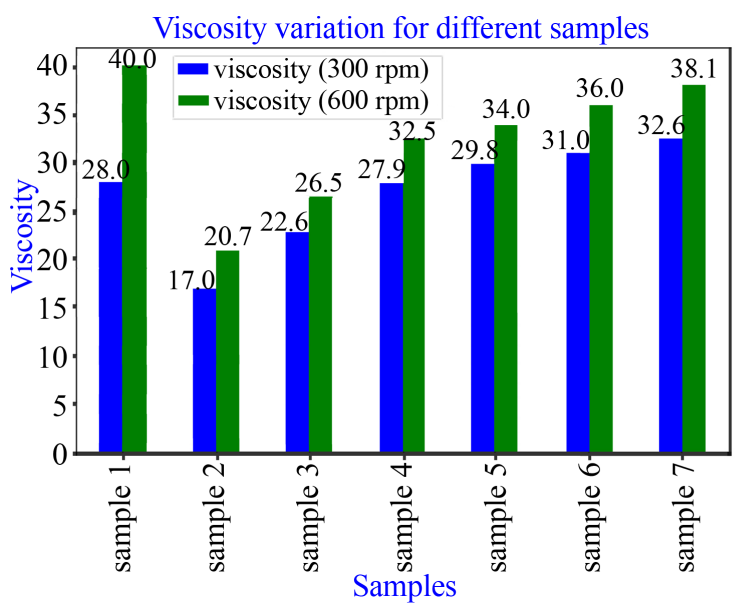

Key

Sample 1; $20 \mathrm{~g}$ imported bentonite Sample 2; $20 \mathrm{~g}$ pure local bentonite Sample 3; $20 \mathrm{~g}$ local bentonite $+3.3 \mathrm{~g}$ $\mathrm{Na}_{2} \mathrm{CO}_{3}+10 \mathrm{~g}$ cassava starch

Sample 4; $25 \mathrm{~g}$ local bentonite $+\mathbf{4 . 2} \mathrm{g}$ $\mathrm{Na}_{2} \mathrm{CO}_{3}+10 \mathrm{~g}$ cassava starch

Sample $5 ; 30 \mathrm{~g}$ local bentonite $+5.0 \mathrm{~g}$ $\mathrm{Na}_{2} \mathrm{CO}_{3}+10 \mathrm{~g}$ cassava starch

Sample 6; $35 \mathrm{~g}$ local bentonite $+5.8 \mathrm{~g}$ $\mathrm{Na}_{2} \mathrm{CO}_{3}+10 \mathrm{~g}$ cassava starch

Sample 7; $40 \mathrm{~g}$ local bentonite $+6.7 \mathrm{~g}$ $\mathrm{Na}_{2} \mathrm{CO}_{3}+10 \mathrm{~g}$ cassava starch

Figure 5. Bar plot showing the viscosity variation of the various samples.

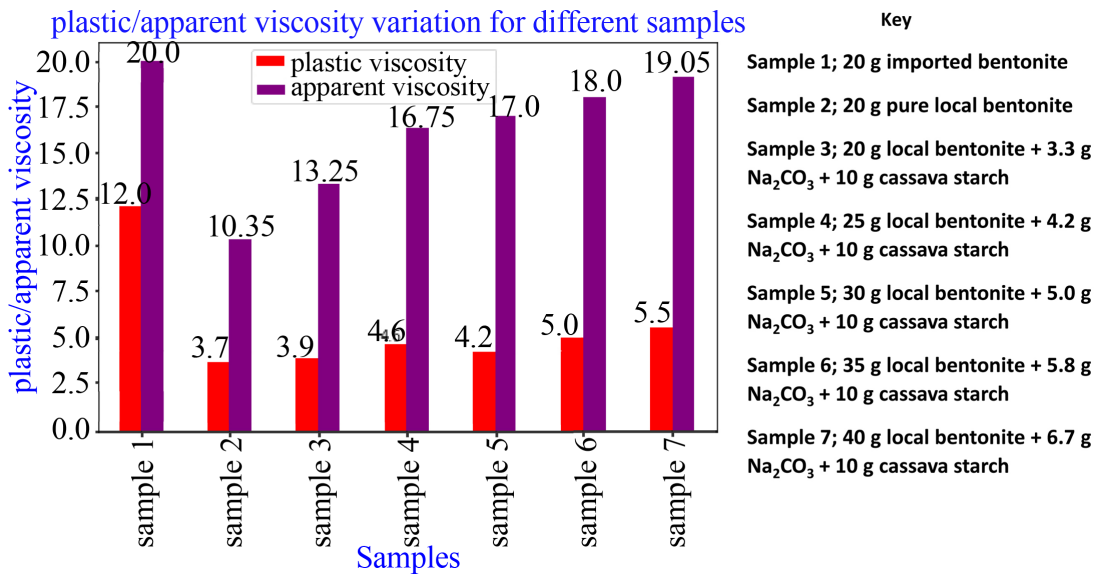

Figure 6. Bar plot showing the plastic/apparent viscosity variation of the various sample.

was relatively low when compared with the standard, and no significant improvement was observed even with an increase in the concentration of $\mathrm{Na}_{2} \mathrm{CO}_{3}$ and cassava starch. 
The measure of the viscosity of a fluid at a given shear rate is known as apparent viscosity. Apparent viscosity is half of the $600 \mathrm{rpm}$ dial value. The apparent viscosity values are dependent on the $600 \mathrm{rpm}$ dial values. Therefore, the highest value at $600 \mathrm{rpm}$ will yield the highest apparent viscosity. From the plot, sample seven ( $40 \mathrm{~g}$ of Local Bentonite Clay $+6.7 \mathrm{~g}$ of $\mathrm{Na}_{2} \mathrm{CO}_{3}+10 \mathrm{~g}$ of cassava starch) had the highest apparent viscosity value. An increased bentonite concentration led to increased apparent viscosity. Compared with the imported bentonite, the values increased progressively and there was significant improvement in apparent viscosity when beneficiated with $\mathrm{Na}_{2} \mathrm{CO}_{3}$ and cassava starch.

The resistance of the initial fluid flow or the needed stress to move the fluid is known to be the yield point. The yield point shows the capacity of drilling mud to transport cuttings to the surface. The yield point calculated from the Bingham equation is less than the true yield stress, which is required to maintain flow [3]. Figure 7 below shows the comparison between the yield point of the standard bentonite, local bentonite, and the five different samples. From the plot, the different yield point values were as the difference between the values of viscosity at $300 \mathrm{rpm}$ and plastic viscosity. Since there was a significant improvement in the reading of viscosity at $300 \mathrm{rpm}$ and a slight improvement in plastic viscosity, the yield point of the samples improved significantly when compared with the imported bentonite.

Figure 8 is a bar chart showing the comparison between the fluid loss of the imported bentonite, local bentonite, and the five different samples. The lower the fluid loss, the more suitable the drilling mud and vice versa. It was observed from the plot that the local bentonite exhibited a very high level of fluid loss when compared with the standard bentonite. But after beneficiation with increased volume of the local bentonite, there was a relative improvement in the fluid loss of the treated samples compared to the untreated local bentonite as the filtration loss of the treated samples reduced drastically compared to the untreated bentonite.

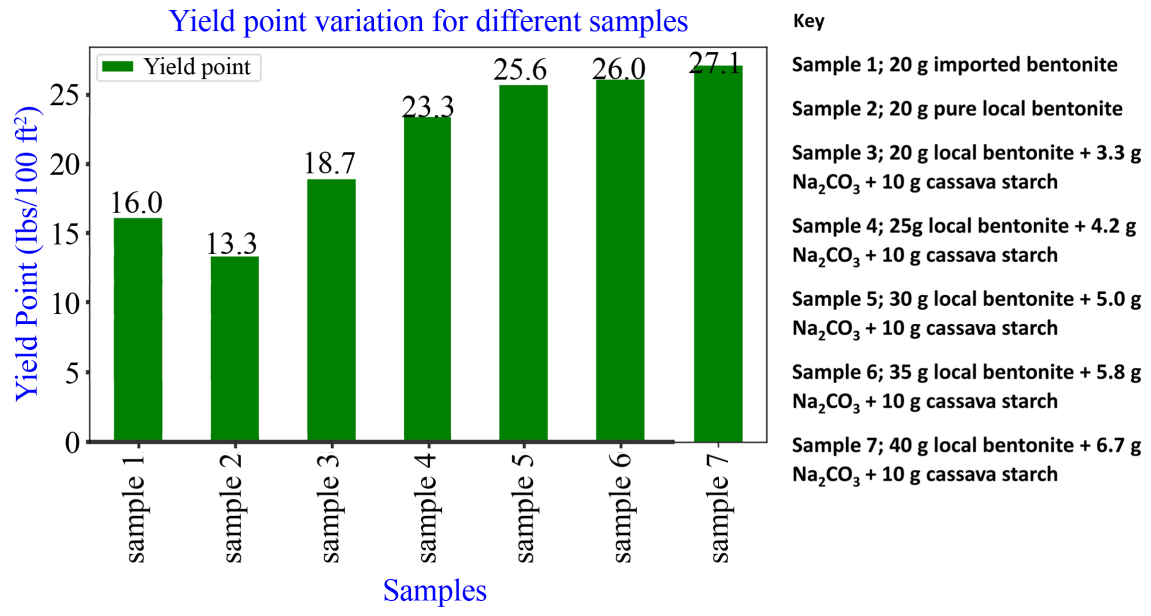

Figure 7. Bar plot showing the yield point variation of the various sample. 
Fluid Loss variat on for different samples

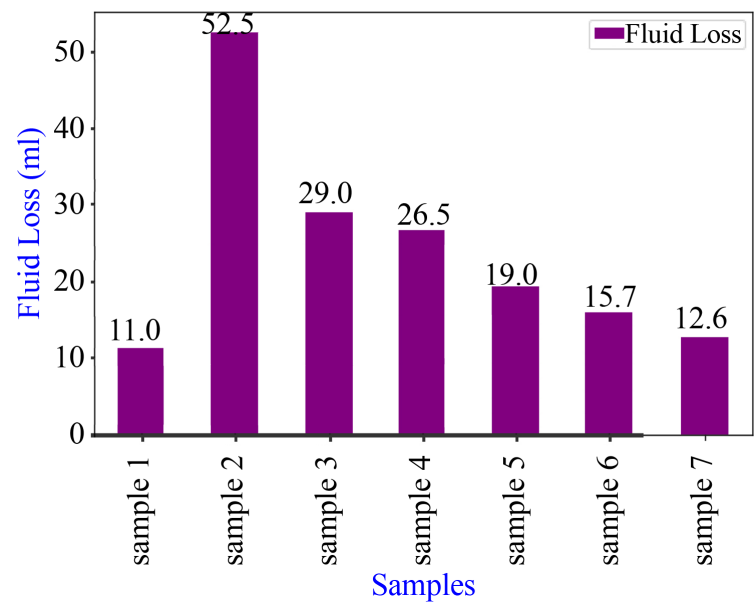

Key

Sample 1; $20 \mathrm{~g}$ imported bentonite Sample 2; $20 \mathrm{~g}$ pure local bentonite Sample 3; $20 \mathrm{~g}$ local bentonite $+\mathbf{3 . 3} \mathrm{g}$ $\mathrm{Na}_{2} \mathrm{CO}_{3}+10 \mathrm{~g}$ cassava starch Sample 4; $25 \mathrm{~g}$ local bentonite $+\mathbf{4 . 2} \mathrm{g}$ $\mathrm{Na}_{2} \mathrm{CO}_{3}+10 \mathrm{~g}$ cassava starch

Sample 5; $30 \mathrm{~g}$ local bentonite $+\mathbf{5 . 0} \mathrm{g}$ $\mathrm{Na}_{2} \mathrm{CO}_{3}+10 \mathrm{~g}$ cassava starch

Sample 6; $35 \mathrm{~g}$ local bentonite $+\mathbf{5 . 8} \mathrm{g}$ $\mathrm{Na}_{2} \mathrm{CO}_{3}+10 \mathrm{~g}$ cassava starch

Sample 7; $40 \mathrm{~g}$ local bentonite $+6.7 \mathrm{~g}$ $\mathrm{Na}_{2} \mathrm{CO}_{3}+10 \mathrm{~g}$ cassava starch

Figure 8. Bar plot showing the fluid loss variation of the various sample for 30 mins.

Sample seven ( $40 \mathrm{~g}$ of Local Bentonite Clay $+6.7 \mathrm{~g}$ of $\mathrm{Na}_{2} \mathrm{CO}_{3}+10 \mathrm{~g}$ of cassava starch) showed the greatest improvement in filtration loss. The presence of cassava starch in the samples helped to reduce filtrate loss as cassava starch is a fluid loss reducer.

\section{Conclusion}

As interest in bentonite usage increases in oil and gas facilities in Nigeria and all over the world, it is necessary to improve the rheological properties of Nigeria's bentonite to make it comply with international API standards. This is necessary to prevent the country from losing huge amounts of money from international oil companies operating in Nigeria in the name of importing high-quality drilling mud. In order to maximize the use of local bentonite for drilling applications, the use of calcium bentonite with sodium carbonate, tapioca starch and other suitable additives becomes important. The results of this study showed that the combination of local clay, cassava starch and $\mathrm{Na}_{2} \mathrm{CO}_{3}$ through heat treatment and mechanical agitation procedures improved some of the rheological and flow properties of the mud samples. The gradual increase in the concentration of bentonite and $\mathrm{Na}_{2} \mathrm{CO}_{3}$ also affected the viscosity and properties of the mud samples. The higher the sodium carbonate concentration, the higher the alkalinity $(\mathrm{pH})$ of the mud sample. Compared to the API standard, the mud sample with the highest concentration of bentonite and sodium carbonate $(40 \mathrm{~g}$ of local bentonite $+6.7 \mathrm{~g}$ of $\mathrm{Na}_{2} \mathrm{CO}_{3}+10 \mathrm{~g}$ of cassava starch) showed the highest flow and rheological properties after the treatment. This means that with higher concentrations of additives, the quality of the local bentonite can be improved to the standards required for drilling operations. In order to increase the viscosity of the local bentonite, further research is recommended to use other chemical additives to change the rheological properties of the mud with economic analysis in view. 


\section{Conflicts of Interest}

The authors declare no conflicts of interest regarding the publication of this paper.

\section{References}

[1] Ademiluyi, F.T., Harry, T.F., Joel, O.F. and Oduola, K. (2016) Performance Evaluation of Local Cassava Starches with Imported Starch for Drilling Fluid. American Journal of Engineering Research (AJER), 5, 111-120.

[2] Afolabi, R.O., Efeovbokan, V. and Orodu, O. (2017) Properties and Application of Nigerian Bentonite Clay Deposits for Drilling Mud Formulation: Recent Advances and Future Prospects. Applied Clay Science, 143, 39-49.

https://doi.org/10.1016/j.clay.2017.03.009

[3] Annis, R.M. and Smith, V.M. (1996) Drilling Fluids Technology. EXXON Company, Houston.

[4] Bourgoyne, A.T., Millheim, K.K., Chenevert, M.E. and Young, F.S. (1991) Applied Drilling Engineering. SPE Textbook Series Vol. 2. Society of Petroleum Engineers, Richardson.

[5] Dewu, B.B., Arabic, S.A., Oladipo, M.O., Funtua, I.I., Mohammed-Dabo, L.A. and Muhammad, A.M. (2011) Improvement of Rheological Properties of Bentonite Clays Using Sodium Carbonate and a Synthetic Viscosifier. International Archive of Applied Science \& Technology, 2, 43-52.

[6] Offiong, A., Okorie, A. and Okon, A. (2016) Activation of Local Bentonite Clays for Use as Viscosifiers in Water-Based Drilling Fluids. Journal of Scientific Research and Reports, 12, 1-11. https://doi.org/10.9734/JSRR/2016/28719

[7] Falode, O.A., Ehinola, O.A. and Nebeife, P.C. (2007) Evaluation of Local Bentonite Clay as Oil Well Drilling Fluids in Nigeria. Applied Sciences, 39, 19-27.

https://doi.org/10.1016/j.clay.2007.04.011

[8] Igbani, S., Peletiri, S.P. and Egba, S.U. (2015) A Study on the Individual Impact of Cassava Starch and Hydroxyl Propyl-Modified Starch on Mud Density. International Journal of Engineering Trends and Technology, 29, 1-5. https://doi.org/10.14445/22315381/IJETT-V29P201

[9] Chilingarian, G.V. and Vorabutr, P. (1983) Drilling and Drilling Fluids. Elsevier, Amsterdam, 149-151.

[10] Elward-Berry, J. and Darby, J.B. (1997) Rheologically Stable, Non-Toxic, High Temperature, Water Based Drilling Fluid. SPE Drilling \& Completion, 12, 158-162. https://doi.org/10.2118/24589-PA

[11] Magzoub, M.I., Nasser, M.S., Hussein, I.A., Benamor, A., Onaizi, S.A., Slutan, A. and Mahmoud, E. (2017) Effects of Sodium Carbonate Addition, Heat and Agitation on Swelling Rheological Behaviour of Ca-Bentonite Colloidal Dispersion. Applied Clay Science, 147, 176-183. https://doi.org/10.1016/j.clay.2017.07.032

[12] Nwosu, D.C., Ejikeme, P.C.N. and Ejikeme, E.M. (2013) Physico-Chemical Characterization of "Ngwo" White Clay for Industrial Use. International Journal of Multidisciplinary Sciences and Engineering, 4, 11-14.

[13] Okologume, W.C. and Akinwumi, A.E. (2016) Comparative Study of Basic Properties of Mud Prepared with Nigerian Local Clay and Mud Prepared with Foreign Clay: A Case Study of Abbi Clay Deposits. International Journal of Engineering and Technologies, 8, 61-71. https://doi.org/10.18052/www.scipress.com/IJET.8.61 
[14] Emofurieta, W.O. and Odeh, A.O. (2012) Rheological Characterization of Shale-Mud Interactions. Energy Science and Technology, 3, 45-50.

[15] Shadravan, A. and Amani, M. (2012) What Every Engineer or Geoscientist Should Know about High Pressure High Temperature Wells. Kuwait International Petroleum Conference, Kuwait City, 12-14 December 2012.

https://doi.org/10.2118/163376-MS

[16] Neff, J.M., McKelvie, S. and Ayers, R.C. (2000) Environmental Impacts of Synthetic Based Drilling Fluids. Report Prepared for MMS by Robert Ayers and Associates, Inc., U.S. Department of the Interior, Minerals Management Service, Gulf of Mexico OCS Region, New Orleans, 1-10.

[17] Emofurieta, W.O. and Odeh, A.O. (2010) Swelling Characteristics of Shales and their Dispersion in Drilling Muds II. Energy Sources, Part A, 33, 12-26.

https://doi.org/10.1080/15567030903076982

[18] Emofurieta, W.O. and Odeh, A.O. (2010) Swelling Characteristics of Shales and Their Dispersion in Drilling Muds III. Petroleum Science and Technology, 28, 1535-1543. https://doi.org/10.1080/10916460903117560 